Steven J. Reid and David McOmish, eds.

Neo-Latin Literature and Literary Culture in Early Modern Scotland. Leiden: Brill, 2017. Pp. xi + 300. Hb, €139.

There is some unevenness in the quality and depth of research undertaken into the neo-Latin literature of Europe's different countries and regions. Scotland is amongst the countries for which some significant and very useful general works and detailed studies have now been produced. A research project at the University of Glasgow (Bridging the Continental Divide: Neo-Latin and Its Cultural Role in Jacobean Scotland), which focused on research into the Delitiae poetarum Scotorum huius aevi illustrium and which gave rise to a series of accompanying works, marked a milestone in recent neo-Latin studies in Scotland. The volume to be reviewed here also ties in closely with this research project, which goes some way to explaining the selection of authors and texts reviewed.

St. J. Reid begins his introduction by lamenting the fact that nobody has produced a reliable, in-depth overview of neo-Latin literature in Scotland despite some initial forays in the past. The situation has only begun to improve in the past decade, he claims, with key texts being edited, projects funded and bibliographies compiled. The University of Glasgow project mentioned above organized a conference that produced the articles collected in this volume. Reid then proceeds to outline some fundamental features of Scotland's neoLatin literature: its close ties to France and other centres of continental Europe, its love of Greco-Roman antiquity, its blossoming in the decades following 1603 - why this year was chosen as starting points, is never explained - and its decline in the late seventeenth century. All the articles in the volume relate to these key themes. The admission is made that it is not yet possible to provide an overview of the neo-Latin written by hand; many questions, such as those concerning the impact of Scottish texts on international circles, have to remain unanswered for now.

In his article "France through the Eyes of Scottish Neo-Latinists: Snapshots from the Delitiae Poetarum Scotorum" (10-39), St. J. Reid looks at the literary contacts between Scotland and France as illustrated by the collection Delitiae poetarum Scotorum for the second half of the sixteenth and the start of the seventeenth century. He looks at writers active at the time of Charles IX (r.156o-74) (Patrick Adamson, Andrew Melville, Thomas Maitland), Henry III (r.1574-89) (James Halkerston, Hercules Rollock) and Henry IV (r.1589-1610) (George Crichton, John Scot of Scotstarvit).

D. McOmish's piece, "A Community of Scholarship: Latin Literature and Scientific Discourse in Early-Modern Scotland" (40-73), asks what role the sci- 
ences, particularly astronomy, played in early modern Scotland. He opens with a discussion of probably the most famous work, George Buchanan's didactic poem De sphaera, and points to the educational reforms of Andrew Melville and the poetry of Thomas Craig as being two areas that show clear traces of a general academic debate about astronomy going on in Scotland. He then goes on to talk about a circle of scholars in Edinburgh that was alluded to primarily in letters and academic publications. This group devoted themselves to an indepth study of astronomy up until the 1620 s and played a key role in guiding the debate, including at a European level.

L.B.T. Houghton's piece in the third chapter, "The Scottish Fourth Eclogue" (74-99), traces the reception of Virgil's Eclogue 4 in Scotland. He begins by addressing the text's political implications, which make it the perfect blueprint for a prince as ruler (Golden Age), drawing on works by George Buchanan, Andrew Melville, and Robert Ayton to substantiate this interpretation of its reception. He goes on to investigate the influence that Eclogue 4 had on Scottish pastoral poetry in general and on Barclay, Anderson, Aidie, and Leech in particular, concluding with a look at the theme of the return of the good king, which James Philp, for instance, borrows from Eclogue 4 in his epic poem Grameis.

In the fourth chapter, "Peter Goldman: A Dundee Poet and Physician in the Republic of Letters" (100-25), W. Poole charts the intellectual biography of Dundonian doctor Peter Goldman, who studied in St Andrews and Leiden and was then active in Paris and Oxford before returning to his home country. As well as being involved in academic correspondence, he is also known for penning several poems (most notably Lachrymae [Paris, 1614], an elegy on the death of his brother, written from the perspective of his grieving mother), which are covered in more detail at the end of the article.

In the fifth chapter, "The King Returns: The Muses' Welcome (1618)" (12662), R. Green discusses The Muses' Welcome to the High and Mightie Prince James, the extensive poetry anthology of 1618 . King James VI travelled across Scotland between May and August 1617, being welcomed to various towns and cities with speeches and poems in Latin (and, very occasionally, in English as well), later ordering many of these to be collected together and published. In his article, Green covers the entire collection, which impressively contains over 130 poems alone (plus speeches and university lectures), in order to conclude by addressing the problems encountered in the edition-some elements of the collection had already been published separately while the king's visit was still ongoing.

In Chapter 6, "Andrew Melville, the 'Anti-Tami-Cami-Categoria' and the English Church" (163-81), R. Cummings discusses an ode in fifty-one Sapphic 
stanzas written by Andrew Melville in 1604 to defend the stance adopted by the "Humble Petition," in which members of the English clergy demanded reforms to the church and for which they faced fierce attacks as a result. With this ode, Melville wades into the debate and launches attacks of his own, chiefly on texts by scholars at Oxford and Cambridge (symbolized by the Rivers Thames and Cam). The poem was published in 1620 and 1623 , at a time when the debate had flared up again.

M. Kerr-Peterson's article, "A Classic Send-Off: The Funeral Oration of George Keith, Fourth Earl Marischal (1623)" (182-202), focuses on the eulogy given in 1623 by William Ogston at the memorial service for George Keith, Fifth Earl Marischal, at Aberdeen's Marischal College. It starts by highlighting why this text was so unusual given that the Protestant reformers had spoken out firmly against funeral orations. Kerr-Peterson then looks at the various sources for the speech, some of which were quoted verbatim. The deceased is described in accordance with the ideals of neo-Stoicism, and the allusion to Tacitus (the deceased's lineage is also traced back to the Chatti) enables a link to be forged with Roman antiquity but also with a tribe that fiercely resisted the Romans-a welcome role model in light of the Scottish Kirk's resistance to Roman Catholicism.

Arthur Johnston (c.1579-1641) is mainly known for editing the Delitiae poetarum Scotorum as well as for his own works, which he penned after returning home to Aberdeen in 1623. A. Farquhar's article, "Arthur Johnston (c.1579-1641): A Scottish Neo-Latin Poet in Europe" (203-22), looks at the poetry that Johnston wrote during his studies in Heidelberg, Sedan, and Padua. He takes as his case study the Propempticon ad illustrissimum principem Ludovicum, comitem Palatinum, ducem Bavariae, a ninety-two-verse elegy dedicated to Ludwig, the brother of the famous Frederick $v$ of the Palatinate, who-like Johnston-also studied in Sedan and was forced to leave in 1617. In her article, "Arthur Johnston's 'Dedication' to the Delitiae poetarum Scotorum" (223-46), G. Manuwald looks at a specific group of paratexts to the collection Delitiae poetarum Scotorum: the dedication and the nine poems (echoing the nine Muses!) penned by Arthur Johnson. In these groups of texts, which make complementary references to one another, Johnston praises John Scot for his major undertaking, putting himself in a rather delicate diplomatic situation given that his own poems also appear in the collection. The letter and poem are published at the end of the article complete with an English translation.

Alexander Broadie in "James Dundas on Seneca, Descartes and the Fall" (247-63), tackles the remaining fragment of the tract Idea philosophiae moralis by James Dundas (c.1620-79), in which the former statesman addresses the idea, developed by Seneca and taken up by Descartes, that it is not fortune but 
wisdom and virtue that make a man lucky. As a Calvinist, Dundas rejects these notions and argues against the Stoics on key issues (e.g. suicide).

Rounding off the volume, R. McLean's "The Decline of Latin in the Scottish Universities" (264-84) takes a look at how Latin developed in the late seventeenth century and going into the eighteenth. He illustrates how universities were holding more and more lectures in both Latin and English or just English; how English was rising above Latin in status amongst certain social groups, e.g. in the clubs; and how theological disputes between different denominations were increasingly being voiced in the vernacular. By referencing selected examples (such as George Mackenzie, author of Aretina, the first Scottish novel), it becomes possible to show when individual authors of this era opted for Latin and when for English.

All in all, anyone reading the eleven articles that make up this volume will gain a vivid impression of neo-Latin literature in Scotland between the sixteenth and eighteenth centuries. Its main focus is poetry, rhetoric, and philosophy, with other disciplines being ignored. The overview of works printed in Latin in Scotland up to 1700 that was compiled by R. Green, P. Burton and D. Ford (Leuven: Leuven University Press, 2012) highlights the fact that the country also produced significant works in many other fields such as medicine and history, to pick but two examples at random. In other words, much remains to be done before Scotland's neo-Latin literature could be said to have been fully explored. Nevertheless, this volume has made valuable inroads into the wealth of material out there and deserves to be seen as a work of reference in whose footsteps later studies will be required to follow. The readers of the present journal who are mainly interested in Jesuit studies, will find no (or very little) information about Jesuits in this volume - the index lists under "Jesuits" only three marginal entries. But in view of the fact that from the sixteenth to the eighteenth centuries Jesuits were among the most important authors of poetry, oratory, and philosophy, the international context of Jesuit production, by means of Scotland as a case study, is well documented in this volume.

\section{Florian Schaffenrath}

Ludwig Boltzmann Institute for Neo-Latin Studies

florian.schaffenrath@neolatin.lbg.ac.at

DOI 10.1163/22141332-00501008-08 